\title{
INTER-UNION DISPUTES IN SEARCH OF A FORUM
}

\author{
BY LOUIS L. JAFFE $\dagger$
}

THE United States has indicted a local of the Teamsters Union ${ }^{1}$ and a local of the Carpenters Union ${ }^{2}$ under the Sherman Anti-Trust Act because each has picketed and boycotted an employer in the course of a "jurisdictional dispute." The employer has filled jobs over which the union claims jurisdiction with members of another union. The action of the Department of Justice is, I believe, a dangerous response to a situation that has become exasperating to the point of madness. The Teamsters have held up the progress of public building in Washington by insisting that they and not the Operating Engineers must man the mobile concrete mixers. The Carpenters have been disputing with the Machinists over the installation of certain types of equipment. ${ }^{3}$ Anheuser-Busch reports that it has thereby been forced to abandon plans for an additional plant costing $\$ 750,000$. Twenty-five years ago, the AFL awarded this work to the Machinists and no amount of conference, cajolery or exhortation could induce the stalwart Carpenters to recognize the award. The Tenmsters and the Carpenters are among the most constant offenders in obstructing production. Hence the action of the Department of Justice is fully understandable, the more so the more we learn of the subject, yet for all of that it is, I believe, dangerous.

The indictment makes distinctions which ring with reminiscence: "The said conspiracy and each of the said acts of said conspirators was not intended to be, nor was it in fact in aid of higher wages, shorter hours, better working conditions for labor or any other legitimate objective of a labor union." 4 And the Department in justifying the indictment states:

"It is not the policy of the government to interfere with practices tending to promote legitimate collective bargaining, to improve hours,

$\dagger$ Professor of Law, University of Buffalo Law School; Member of California Bar.

I wish here to thank my wife, Mildred Miles Jaffe, sometime Assistant Professor in the University of Buffalo Law School, for her cooperation in the research upon which this Article is based.

1. N. Y. Times, Oct. 13,1939 , p. 1, cols. 2 and 3. The indictment charges Local No. 639 of the International Brotherhood of Teamsters for conspiring to delay government building work by strikes, violence, boycotts, etc.

2. N. Y. Times, Nov. 4, 1939, p. 9, col. 4. The indictment charges that William L. Hutcheson, general president of the United Brotherhood of Carpenters and Joiners of America and Brother Officers wilfully engaged in a conspiracy in restraint of trade "with the effect and intent of imposing a direct and unreasonable burden" on trade and commerce with unlawful purpose of "inducing and coercing an employer to violate a contract with one group of employees and replace them with another group."

3. See Procendings of American Federation of Labor (1914) 417 ; (1915) 403 et seq.; (1916) 376; (1918) 127; (1919) 464; (1921) 140; (1932) 409-22; (1933) 114.

4. See notes 1 and 2 sipra. 
wages, health, safety or working conditions. It recognizes the privilege of organization granted to labor by statute and the common law. It is only when the privilege is used in a manner that is clearly unreasonable and unlawful that the government intervenes." (Italics added).

Though it is not the purpose of this Article to consider whether the anti-trust acts do apply to this situation, it should be noted, parenthetically, that in Levering \& Garrigues v. Morrin, the Supreme Court held that a strike by a building union for a closed shop which impeded the erection of a building did not restrain interstate commerce within the Sherman Act. ${ }^{6}$ In this respect the case is strikingly similar to the St. Louis matter involving the Carpenters. Perhaps the Department of Justice vill argue that the increase of federal power under the Wagner Act carries with it an increase of power under the Sherman Act even without amendment, a proposition which the Supreme Court appears so far to have denied. Turthermore, is it so clear that the pursuit of jobs and of members is not a "legitimate" object of a labor union? In 1932 Chief Judge Pound and all but one of the judges of the New York Court of Appeals held that these objectives were within the realm of legitimate economic conflict and refused to enjoin picketing by a rival union. ${ }^{8}$ Granting, however, that these particular objectives are not legitimate, is a strike for a closed shop "legitimate?" Is a boycott "legitimate?" Thurman Arnold, Assistant Attorney-General in charge of the Anti-Trust Division, and upon whose authority it must be supposed these indictments were sought, may reply: of course, they are legitimate; we shall take no action against them. But there are many judges who do think otherwise. For instance, Mr. Justice No-Love-Lost-on-Labor will say: the government itself uses the anti-trust acts to curb illegitimate labor activity; we shall follow suit, though of course, it is for us to say what is illegitimate. Mr. Arnold has written two books devoted to the proposition that laws are symbols rather than rational, definite propositions. They are the sacramental mumbo-jumbos which enable judges to impose their decisions upon the credulous and the vulgar. The anti-trust laws particularly are a veil of pretense behind which corporations are allowed to grow big and labor unions are discouraged. Is it unjustly literal to ask whether the anti-trust laws are no less symbolic when Mr. Arnold sets them in motion in 1939 than when he writes about them in 1938? Mr. Arnold now distinguishes between that which the "law" considers "legitimate" and "illegitimate."

5. United States v. Local No. 639 of Int'l Brotherhood of Teamsters, No. 64706 (D. D. C. 1939), Dep't of Justice Release, Oct. 12, 1939.

6. 289 U. S. 103 (1933).

7. N.L.R.B. v. Jones \& Laughlin Steel Corp., 301 U. S. 1, 40 (1937).

8. Stillwell v. Kaplan, 259 N. Y. 405,157 N. E. 130 (1932).

9. The Syarbols of Governarent (1935); The Folmoore of Capitalisur (1937). 
Yet he has taught us that the law - and this one in particular - is without rationally definable content. Nevertheless, there is still a good deal to his original conception of the anti-trust laws. The "rational" distinctions which he now makes will not be so objectively inevitable that everyone else is bound to make the same ones. Perhaps there would be no danger if he alone initiated the application of the law. Indeed, $\mathrm{Mr}$. Arnold has indicated that he will prosecute only where there is interference with "an established and legitimate system of collective bargaining." 10 But there will be other attorneys-general after him, and there is always the possibility of a suit by a private party for triple damages. Last spring, the Apex Hosiery Company recovered judgment for over $\$ 700,000$ against the American Federation of Hosiery Workers in a suit for triple damages under the Sherman Act for loss caused by a sit-down strike. $^{11}$ Although this decision was recently set aside, ${ }^{12}$ in it still lies the possibility of bankrupting union treasuries.

The last four years have demonstrated the sensitivity of judges to public opinion. Courts which had previously been hostile to labor, have come, under the pressure of the New Deal and the opinion it represents, to coo like doves at the very mention of collective bargaining. The NorrisLaGuardia Act has been given the broadest possible construction by the Supreme Court, to the admiring applause of liberals. Indeed it seems that in the very type of case which now gives rise to criminal indictment, the courts hold themselves forbidden to grant an injunction. ${ }^{13}$ Liberals

10. N. Y. Times, Nov. 20,1939 , p. 1, col. 4, p. 12, col.1. See p. 458 infra for a discussion of this statement.

11. Apex Hosiery Co. v. Leader, C. C. H. Labor Law Serv. $\mathbb{1 8 , 3 3 6}$ (E. D. Pa. 1939). Motion for retrial dismissed April 24. C. C. H. Labor Law Serv. $\Uparrow 18,353$ (E. D. $\mathrm{Pa}$. 1939). No opinion was written in this case. The treble damages awarded by the court were $\$ 711,932.55$. In his instructions to the jury, Kirkpatrick, J., stated that the facts had been ruled upon by the circuit court of appeals in an action for injunctions under the Sherman Act, the Clayton Act and the National Labor Relations Act. Apex Hosiery Co. v. Leader, 90 F. (2d) 155 (C. C. A. 3d, 1937) ; on appeal to the Supreme Court, the 1937 case was dismissed as moot, the strike having been settled. 302 U. S. 656 (1937).

12. 5 LAB. REL. REP. 353 (C. C. A. 3d, 1939), decided on authority of Levering v. Morrin, 289 U. S. 103 (1933).

It appears [N. Y. Times, Nov. 23, 1939, p. 30, col. 4] that Mr. Arnold is prepared to argue in favor of the Union in the Apex case on the ground that the ends were legitimate; he must thus take the further position that the legitimacy of the means (here a sit-down strike much disfavored by the courts) is immaterial. But few courts will be inclined to permit illegitimate means, however valid the ends. Perhaps he is prepared to argue that the restraint in the jurisdictional dispute is "material" whereas in the Apcx case it was not. In the Apex case the court seemed inclined to argue that not only was there no "direct" restraint but no "material" one. This is a suggestion of the monopoly test applied on behalf of industrial combinations ("rule of reason") but hitherto rejected for labor unions.

13. Lauf v. Shinner, 303 U. S. 323 (1938); International Brotherhood of Teamsters v. International Union of Brewery Workers, 5 LAB. REL. REP. 112 (C. C. A. 9th, 1939); Houston v. North Texas Motor Freight Lines, 24 F. Supp. 619 (W. D. Okla. 1938); 
have fought hard to curb the power of the courts to cripple labor by inspired reading of the vague phrases of the anti-trust laws and expansive conceptions of equity jurisdiction. In an era when liberals have secured a measure of political power, the courts have seen fit to relinquish some of this jurisdiction. But there are surely some courts which have yicled more from pressure than conviction. The New Deal has been the avowed champion of labor. Once let this government fire a shot (however justly in the particular case), it may be heard (however unjustly) as an announcement of open season. Shooting will become general and the hounds will begin to run.

Yet the jurisdictional dispute gives rise to real evils. Labor and those who fight for labor have refused to take these evils seriously. On countless occasions they have gravely deplored jurisdictional disputes, but rarely have they been willing to support any method for dealing with them effectively or mitigating their impact on outsiders, be they workers or employers. ${ }^{14}$ This is quite understandable. Any solution will necessarily involve some loss of autonomy or some restriction imposed by judicial or administrative action upon strike, picket and boycott. Tntil very recently, labor has been entirely on the defensive. The intervention of the state has been almost uniformly on behalf of its enemies. Labor has not been in a position to offer reasons why injunctions should go against them or admit that any injunction was good. The injunctions would continue to issue, the reasons and distinctions would be forgotten. Furthermore, the jurisdictional dispute is not entirely evil, any more than partisan politics is entirely evil. Both are mechanisms of representative government whereby the leader seeks his constituency and in turn is tried and discarded, whereby the group in order better to fulfill its function seeks to augment its membership.

Labor now is sometimes plaintiff. The labor boards express its aspirations, seek to protect it in the process of collective bargaining, to compel a certain minimum of cooperation by the employer in dealing with its representatives. In the federal and many state courts, the use of the injunction is restricted. ${ }^{15}$ There is, consequently, less reason for opposition to any authoritative mechanism for protecting production from the blight of the jurisdictional dispute. Labor's indifference will beget prosecutions under the anti-trust law or, as in Oregon, repressive anti-

Grace Co. v. Williams, 20 F. Supp. 263 (W. D. 110. 1937), aff'd, 96 F. (2d) 478 (C. C. A. 8th, 1938) ; Cupples Co. v. American Federation of Labor, 20 F. Supp. 894 (E. D. Mo. 1937) ; Sharp \& Dohme, Inc v. Storage Warehouse Emplayees Union, 24 F. Supp. 701 (E. D. Pa. 1938).

14. E.g., Brooks, Untons of Their Own Choosrisg (1939) discussed infra g. 456.

15. Sixteen states have anti-injunction statutes similar in tyne to the Norris-LaGuardia Act: Colorado, Idaho, Indiana, Louisiana, Maine, MIaryland, Mfassachusetts, Minnesota, New York, North Dakota, Oregon, Pennsylvania, Utah, Washington, Wisconsin and Wyoming. 
labor laws. ${ }^{16}$ In Oregon, public support for such a law was won by the experience of a general stoppage for three months of the lumber industry by carpenters, teamsters and longshoremen, despite or because of the formal certification by the National Labor Relations Board of a CIO union. ${ }^{17}$ Labor can rightly claim that these steps are reactionary. But those who deplore such laws, who shout reaction at each new assault, must be prepared for more and more reaction if they persist in treating these disputes as their own private business and employ all their ingenuity in pointing out the "dangers" of any attempt to deal authoritatively with them. There are dangers in any authoritative solution, but they should be balanced against the dangers of even worse solutions, assuming that the anarchy of no solution is not in itself a reason for running some risks.

The application of the anti-trust laws is one method of authoritative solution. Undoubtedly it may frighten a few of the worst offenders and some unions are notoriously worse than others - into more seemly ways. But we may well fear that it is a clumsy, dangerous instrument which may fall into the hands of the enemy. This Article will examine the other possible solutions and the experience with them both for the light thrown on the conduct of the Department of Justice and on the possibilities of a better solution.

16. Ore. Laws 1939, c. 2. The law prohibits picketing except in a labor dispute which it defines as an "actual bona fide controversy in which the disputants stand in proximate relations of employer and the majority of his employees" and which concerns wages, hours or working conditions. The definition specifically excludes "disputes between organizations or groups of employees as to which shall act" as representatives. Id. at $\S \S 1,3$.

The Oregon law was approved by a vote of 197,771 to 148,460 at the general election, Nov. 8, 1938. It has been held constitutional by the Oregon circuit court in a suit for a declaratory judgment. A.F.L. v. Bain, 4 LAB. REL. REP. 824 (Ore. 1939). A similar law submitted in California met with a decisive defeat. In Washington at the same election an act making strikes unlawful unless authorized by a majority vote of the employees was defeated by a margin of about 9 per cent (1938) 3 LAB. REL. REP. 331. The 1939 amendment to the Wisconsin Anti-Injunction Act. [Wis. Laws 1939, c. 25] restricts the definition of "labor dispute" to any controversy between an employer and the majority of his employees in a collective bargaining unit. And the Penmsylvania law has been amended [Pa. Laws 1939, Act 163] so that injunctive relief shall be available where a labor dispute breaches a valid contract between an employer and the representative of his employees as selected under the state or National Labor Relations Act if the complainant has not committed an unfair labor practice or breached the contract; when a union tries to compel an employer to require his employees to join it before it has gained a majority or while an attempt is made to coerce an employer to violate the state or National Labor Relations Act; or where employees seize or damage plant or other property of an employer.

17. TrMe, Nov. 29,1937, p. 15 . The NLRB certified CIO in seven of biggest sawmills. Notwithstanding, Carpenters (AFL) picketed and Teamsters refused to handle product of mills. In turn, Longshoremen (CIO) refused to handle product of mills dealing with AFL Carpenters. 


\section{The American Federation of Labor as a Forubs for the Settlement of Jurisdictional Disputes}

Early in its history, the National Labor Relations Board was asked to determine whether the "machine-fixers" in two large tobacco plants were to be represented for purposes of collective bargaining by the International Association of 'Machinists, or by the Tobacco WTorkers' International Union. Admittedly the Machinists Union was the chosen representative of the so-called Machinists proper; the Tobacco Workers of the industrial employees exclusive of the men in question. The two international unions disputed jurisdiction over the fixers. The question of jurisdiction as such was not the question before the Board. The Act authorizes it to determine "appropriate units" for collective bargaining, and these determinations do not necessarily follow or purport to follow the lines laid down by union charters. ${ }^{18}$ In nearly all instances, the unit has included no more than the employees of a single employer or some portion of them. ${ }^{19}$ The purpose of the determination is to secure a representative to deal with the employer. Charter jurisdiction and trade classifications are not the only criteria of appropriateness. These are drawn, as well, from the history of the relations between the workers and the employer in question. If, for example, the plant has been organized on an "industrial" basis, and collective bargaining has been carried on consistently by a single trade union representative, it will be held that a single plant-wide unit is appropriate and craft lines will be ignored.9.9 Under

18. Section 9 (b) of the NLRA provides: "The Board shall decide in each case whether, in order to insure to employees the full benefit of their right to self-organization and to collective bargaining, and otherwise to effectuate the policies of this act, the unit appropriate for the purposes of collective bargaining shall be the employer unit, craft unit, plant unit, or subdivision thereof."

19. But in Shipowners' Ass'n of the Pacific Coast, 7 N.L.R.B. 1002 (1938), longshoremen on the Pacific Coast were treated as a unit, because colleetive bargaining had in the past (under the auspices of the AFL) been carried on between a cosst-wide association of employers and one union. The AFL which lost the election-and on a port basis would have won four of the smaller ports-deeply resented this decision. It is one of the chief counts in their charge that the National Labor Relations Board favors the CIO. See Analysis of Senate Bill 1000 (1939) 4 LAB. ReI. REP. 18S. It is interesting to note in this connection that the CIO in recognition of AFL majorities in Tacoms, Washington, and three adjacent ports has agreed not to assert its right to preferential hiring in those ports, and has embodied the agreement in a covering memorandum attached to its agreement with the employer's association. (1938) 3 LNB. REt. Rep. 180.

The amendment to $\$ 9$ (b) proposed by the AFL includes a provision "that an appropriate unit shall not embrace employees of more than one employer. Two or more units may, by voluntary consent, bargain through the same agent or agents with an employer or employers, through agent or agents." (1939) 3 LAB. ReI. REP. 674.

20. Huth \& James Shoe MIfg. Co., 3 N. L. R. B. 220 (1938); Daily Mlirror, Inc., 5 N. L. R. B. 362 (1938); Fried, Ostermann Co., 7 N.L.R.B. 1075 (1938); American Can Co., 14 N.L.R.B. Nos. 1177-S (1939), (1939) 4 Lab. ReI. Rep. 849. 
the so-called Globe doctrine, ${ }^{21}$ craftsmen who do have a history of plant organization may by a majority vote throw in their lot with an allcompany unit. ${ }^{22}$ Thus it will be a matter of history and choice whether the representative in any one plant will follow the jurisdictional lines of charters. Of course there may be no plant history and the Board may have to make a decision on the basis of job analysis. Though it does this for only the plant in question, still its decision may bear closely on the merits of the jurisdictional dispute.

In the Tobacco cases, the Board refused to intervene, at least in so far as it was asked to assign, for purpose of collective bargaining, the fixers to one or another of the warring camps. ${ }^{23}$ This involved, it said, a jurisdictional dispute between unions subject to a common federation. It was more appropriate that the Federation should settle this family quarrel. "Such a question," said the Board "involving solely and in a peculiar fashion the internal affairs of the American Federation of Labor and its chartered bodies, can best be decided by the parties themselves." 24 The Board went on to quote the reasons given in its excellent opinion in the earlier Alumimum case :25

“. . . The availability of the Board as a convenient forum for the airing of such problems would induce the parties to present them to the Board without first having made any real attempt to compose their clifferences among themselves. The consequent accumulation of cases on its docket would considerably hamper the work of the Board. Nor do we feel that the petitioner itself after a full consideration of the implications of its request would desire the Board to pass judgment upon such matters.

"'It is preferable that the Board should not interfere with the internal affairs of labor organizations. Self-organization of employees implies a policy of self-management. The role that organizations of employees eventually must play in the structure established by

21. Globe Machine \& Stamping Co., 3 N.L.R.B. 294 (1937).

22. See (1939) 3 LAB. ReE. REP. 674 for the proposal of the AFL to amend the Labor Act by a provision which would tend to prevent such an occurrence: "That when a craft exists, composed of one or more employees, then such craft shall constitute a unit appropriate for the purpose of collective bargaining for such employee or employecs; a majority of such craft employees may designate a representative for such unit."

23. Axton-Fisher Tobacco Co. \& Int. Ass'n of Machinists, etc.; Brown \& Williamson Tobacco Corp. \& Int. Ass'n of Machinists, etc., 1 N.L.R.B. 604 (1936).

24. Id. at 609 .

25. Aluminum Co. and Aluminum Workers, 1 N.L.R.B. 530 (1936). This case did not strictly involve a jurisdictional dispute. The question was whether the president of the AFL had power to supersede the authority of a federal union in negotiating a labor agreement covering the members of the union. Federal unions are chartered directly by the Federation and are under its control or supervision. The issue, thus, was not in what unit or union the workers belonged but who under the constitution of the AFL was authorized to act for the union. The reasons quoted in the text are peculiarly applicable to such a controversy. 
Congress through that Act is a large and vital one. They will best be able to perform that role if they are permitted freely to work out the solutions to their own internal problems. In its permanent operation the Act envisages cohesive organizations, well-constructed and intelligently guided. Such organizations will not develop if they are led to look elsewhere for the solutions to such problems. In fine, the policy of the National Labor Relations Act is to encourage the procedure of collective bargaining and to protect employees in the exercise of the rights guaranteed to them from the denial and interference of employers. That policy can be best advanced by the Board's devoting its attention to controversies that concern such fundamental matters." "26

The Board has done wisely well to dwell on the pre-eminent moral values of self-government. Samuel Gompers probably caricatured the point when, after lamenting that "in the main, contentions have not abated nor have decisions been respected or complied with," he happily noted that these disputes "have developed a high order of intelligence in discussion among our unionists, keen perception in industrial jurisprudence." 27 This illumination affords, no doubt, many a merry and satisfying debate in convention. It is basic to our liberalistic philosophy that it is worth paying high to allow a maximum of self-government. It stimulates the individual to a fuller, more creative use of his faculties and so enriches his experience and adds to the sum total of his satisfaction. We hope, too, that by invoking participation in a high degree of those more immediately concerned, we shall secure more comprehensive and workable solutions. These hopes are enough in themselves to justify autonomy where the questions for decision affect solely those represented in the organization. But it cannot be admitted that a question of jurisdiction is, as the Board says, "solely the internal affair" of the Federation. If by that is meant that the frustration of the workers" right to choose their bargaining agent or the stoppage of production by boycott and picket is an internal affair, it is obviously not true. The employer has not submitted his interest to adjudication by the Federation nor have those of his workers who are not members of any of its unions. The Board is asked to deal with one of the effects of a failure by the Federation to settle a question of internal policy. It does not settle the question itself, though, of course, its determination may have repercussions within the Federation. It may be significant that the Globe doctrine, whereby the choice might have been put up to the men, had not yet been developed. The mere fact that the workers may choose a representative in spite of the failure of the Federation to solve the juris-

26. Axton-Fisher Tobacco Co. \& Int. Ass'n of Arachinists, etc; Brown \& Wiillamson Tobacco Corp. \& Int. Ass'n of Miachinists, etc., 1 N.L.R.B. 604, 609 (1936).

27. Proceedings of the Amirrican Federation of Lazor (1905) 23. Hereafter these proceedings will be cited simply, c.g., Proc. (1905). 
dictional question may weaken the position of one of the parties to the dispute and so either strengthen or weaken the hand of the Federation, depending on which party it favors. We may take it as a major premise that the Federation should be left as far as possible to settle these disputes. If it were generally the case that the Federation succeeds in so doing, the protection and fostering of a process so valuable might well involve non-interference with the external ill-effects of an occasional failure. But if it is not so, we should eschew the hopeful generality, face the fact and consider its bearing.

The constitution of the Federation does not specifically provide any machinery for settling jurisdictional disputes. In 1892 the Committee on Grievances, to which at that time jurisdictional disputes were referred, reporting on the complaint of the Furniture Workers against the Carpenters (a dispute which was not to be laid to rest for 20 years), recommended "that the two bodies come together and try to form a plan by which they can work in harmony. Your Committee do not believe it lies within their province to take any other action, as the Constitution gives to each body the right to control its own affairs." 28

The reference apparently is to Article IX, Section 5: "While we recognize the right of each trade to manage its own affairs, it shall be the duty of the Executive Council, to secure the unification of all labor organizations, so far as to assist each other in any trade dispute."

In 1900 a resolution was offered that the International Typographical Union, which had refused to arbitrate a dispute as suggested by the previous convention, be suspended. ${ }^{20}$ But the Committee on Grievances proposed and secured the acceptance of a substitute:

"While we concede that in this controversy the I.T.U. is within its constitutional powers in reserving to itself the right to say whether or not the dispute between that union and the I.A. of M. on the linotype controversy shall be arbitrated we deeply regret that the I.T.U. did not accept the expressed desire of the American Federation of Labor in the Detroit Convention, to submit the dispute to a fair tribunal for adjustment, and instead of declaring by vote or otherwise that we shall take no action in the premises, or that the charter of the I.T.U. be revoked, the American Federation of Labor in convention assembled pledges its good services for further mediation between the organizations concerned and directs the incoming Executive Council to stand ready to act in that capacity should opportunity of doing so present itself during the incoming year." ${ }^{80}$

A general resolution of the same tenor was adopted. It was resolved that in order to eliminate friction and induce parties to make a serious effort at conciliation, the Federation would not take jurisdiction unless

28. Proc. (1892) 34.

29. PROC. (1900) 150.

30. Proc (1900) 150. 
the parties consented to abide by its decision. ${ }^{31}$ It was not likely that this mild view of the Federation's powers would be proof against extreme provocation. Between 1900 and 1910, the irritation caused by jurisdictional disputes became acute. Gompers in report after report commented dolefully on the failure of the Federation to settle jurisdictional disputes. $^{32}$ In 1902 the Charter of the American Society of Engineers was revoked. Gompers said that this was done under stress of "intense feeling and excitement," ${ }^{33}$ and persistently expressed the opinion that revocation was ineffective and contrary to the philosophy of the labor movement. Solutions based on consent he held to be the only ones worth having. But there can be no doubt now that the Federation is empowered to interpret the charters it has issued and exclude from its association those who refuse to abide by its judgment. This is only obliquely recognized by the constitutional provision added in 1907, that the Executive Council may be authorized by a two-thirds vote of the Convention to revoke a charter. ${ }^{34}$ Nevertheless, the weapon of revocation or suspension is of limited utility. ${ }^{35}$ The Federation, with an occasional inexplicable exception, ${ }^{36}$ will rarely invoke it even in support of its considered and reiter-

31. Proc. (1900) 146-7.

32. Proc. (1904) 22; (1905) 23; (1907) 44, 45.

33. Proc. (1907) 44.

34. Article IX, $\$ 12$ : "The Executive Council of the American Federation of Labor shall only have power to revoke the charter of an affiliated National or International Union when the revocation has been ordered by a two-thirds majority of a regular Convention of the American Federation of Labor, by a roll-call vote."

35. Does the provision quoted in the previous footnote require a vote of two-thirds of a convention to authorize the Executive Council to "suspend" a union or for "suspension" by the Convention itself? Practice has settled the proposition that the Council may suspend without any authorization at all and a mere majority of Council or Convention is enough. It is said that suspension simply prevents the penalized union from exercising its vote, and that because its jurisdiction remains it is not like a revocation. Proc. (1925) 269-270. Thus, in 1936 the Executive Council suspended the CIO unions for "dualism" and then secured convention ratification by a majority of those present, excluding those suspended. There would have been a majority in any case though probsbly not the twothirds needed for revocation. Proc. (1936) 65-\$6, 503 et seq. The vote appears at p. 552. The constitution is not clear whether the Conzention must revole by two-thirds rote or whether it has the power at all. Article IX, $\$ 12$ relates by its terms to authorizing the Executive Council to revoke. Matthew Woll seems to argue that the Convention might revoke by a simple majority. Id. at 515 .

36. In 1924 the Executive Council awarded the drivers of the Railway Express Company to the Teamsters Union though most of them had been organized by the Railway Clerks Union. Proc. (1924) 84. This decision was in itself unusual since there scem to have been no previous conferences or attempts at voluntary settlement without which the Federation rarely ever makes an authoritative decision. Indeed the Constitution provides (at present Art. III, \$12) that no grievance shall be considered by any Convention "where the parties thereto have not previously held a conference and attempted to adjust the same themselves."

The Convention on the suggestion of the Executive Council authorized it to suspend if the clerks did not within 90 days comply with the decision of the previous year. Proc. 
ated declarations of jurisdiction, at least until years of conferences and arbitrations have worn out even the half-humorous assumption that the dispute is arbitrable - and then rarely against a powerful union. In 1915, when a committee brought in a resolution for ousting the Carpenters (who have acted on the consistent, indomitable principle that they will never accept any unfavorable decision), a member of the committee admitted that the resolution was not seriously pressed, but had been presented to silence those who complained that only the charters of weak unions were revoked. $^{3 \pi}$ In this instance the Carpenters disdained to oppose the resolution or defend their position. Indeed, Andrew Furuseth of the Seamen suggested, unrebuked, that the Carpenters were provoking the ouster so that they might carry on their raids without being railed at by their victims or scolded by the pious members of the Federation. ${ }^{38}$ The resolution was, of course, defeated. A revocation or threat of revocation may be effective against a small union which relies heavily on the goodwill of the labor movement. Occasionally a large union, such as the Railway Clerks, has been ousted and has subsequently capitulated..$^{30}$ The Federation does have a few other sanctions. An instruction to the state and city central federations not to cooperate with the locals of the recalcitrant union may seriously penalize them, particularly where, as in the building trades, the sympathetic strike and boycott is customary. Curiously, unions have objected that even such discipline is improper. In 1905 the Convention, after refusing to authorize revocation of the charter of the Brewery Workers, resolved that all national, state, and local organs of the Federation "exert every influence and power at their command to make the above decision [settling a jurisdictional dispute] operative and effective." 40 The Brewers objected to this on the ground that it was a "police" method. It undoubtedly was, and there is certainly now no question that such methods are accepted as part of the legitimate machinery of the Federation.

Combined with the indeterminate character of the procedure and the limited effectiveness of the sanctions is the inevitable absence of clear standards of judgment. Some of the earliest charters define jurisdiction quite broadly. That about which there has been most dispute, the Brewers' charter, gave to the union jurisdiction over all "brewery workers." This was in 1887 when narrow principles of trade and craft unionism had not crystallized, when unionism as a whole had collapsed, and when any organization which seemed able to advance energetically into the

(1925) 260-270. This authority was exercised. Proc. (1926) 45. In 1928 the Executive Council is gratified to report an agreement between the Clerks and the Teamsters and the reinstatement of the Clerks in the AFL Proc. (1928) 65, 66.

37. Proc. (1915) 407.

38. Id. at 413.

39. See note 36 supra.

40. Proc. (1905) 223. 
vast no-mans-land of the unorganized was given leave to go ahead. Charters subsequently predicated on trade lines conflicted with the earlier ones. At the end of the century, the trade unionists were pressing resolutions that the Federation was "eternally opposed" to encroachments on craft jurisdiction. In 1900 the constitution was amended to provide that no charter should be granted without "a positive and clear definition of the trade jurisdiction" of the applicant, and the charter shall not be granted if the jurisdiction claimed is "a trespass on the jurisdiction of existing affiliated unions." Howevermuch this might help in the future. it did not solve inherited problems. In 1900 the Grievance Committee in a resolution adopted by the Convention said: "We find ourselves confronted with the undesirable task of limiting on the one hand what is popularly regarded as trade autonomy; or on the other, of disintegrating a composite organization which while in existence has demonstrated its ability both to protect and advance the interests of its members. In such cases we are strongly of the opinion that narrow conceptions of strict trade autonomy should give way. We desire further to say that this body can not, in our opinion, presume to transfor bodies of men from one organization to another, unless with thcir [i.c., the men or the organizations' or both?] consent."41 The italicized words reflect the view of Federation power prevailing in 1900. In 1901 the Convention adopted the so-called Scranton Resolution, a rather vague wishful statement which was intended permanently to settle the question by leaving it where it found it. ${ }^{42}$

This resolution emphasizes the superior position of a craft claim but admits exceptions for occasional deviations which have grown up because of special historical, geographical and economic factors. Thus in 1900 the Convention gave engineers and firemen, who were then organized by the Brewery Union, to the Brewery Union. ${ }^{43}$ If by this was meant, and it was later so held (at one stage of the controversy) ${ }^{1 / 2}$ that engineers and firemen would be divided between unions depending on their membership at the time of decision, it might seriously split the labor front in any one plant. And in these judgments of Solomon there is rarely present any "true mother" who will withdraw her claim in order to keep the baby whole. The Federation has found it difficult to formulate any consistent policy for settling disputes of this sort, the weight to be given to the relevant factors often depending on the adrocacy and strength of the party putting them forth.

It is equally difficult to formulate criteria for drawing the lines between crafts which work on closely related or interchangeable operations.

41. PRoc. (1900) 146. (Italics added).

42. Proc. (1901) 240. The Resolution admits the difficulty of drawing craft lines and urges amalgamation and arbitration as a remedy for excessive classification.

43. Proc. (1900) 67-68.

44. Proc. (1902) 208. 
In part this is the result of faulty or incomplete definition, but draftsmanship can never eliminate the problem, because the rapid shifts in technological process and in material constantly change the nature of the jobs to be done. If a metal door is substituted for a wood door on a building job, is the installation to be done by a carpenter or a sheet metal worker? Is it the nature of the job or of the material which governs decision? There is no overwhelming logic which dictates either choice. ${ }^{45}$ To be sure, that may be true of many choices which must be made by a court. But here there is wanting not only the persuasive quality of decisions validated by objective standards of judgment; there is no determinate procedure, no effective sanction and no inclination to accept the decision. The Federation has been unable to develop, at least among the dominant unions, a conviction that the need of an authoritative tribunal is in itself a sufficient reason for accepting its determination.

A few examples may serve to give meaning to these rather general observations. Let us first consider the dispute between the Woodworkers (Woodworkers International Union, Amalgamated) and the Carpenters and Joiners Union. It was first brought before the Convention in 1901.40 The Convention adopted a resolution of its committee which found that the Carpenters had in 1894 conceded to the Woodworkers jurisdiction over mill hands, millwrights, and stairs builders, roughly persons making wood objects with factory machines, and that the Carpenters had consistently violated this so-called agreement by initiating such persons. ${ }^{47}$ The Convention recommended a further effort by the parties at adjustment. In 1902 the Carpenters, resorting to a familiar tactic of defense, sought unsuccessfully to secure the revocation of the Woodworkers' charter. ${ }^{48}$ Instead, the Convention ordered the parties to arbitrate. ${ }^{40}$ In 1903 the Carpenters claimed that the arbitral award was procedurally defective and were overruled by the Convention. ${ }^{50}$ In 1904 the Executive Council was authorized to suspend the Carpenters' charter unless the Carpenters complied. ${ }^{51}$ In 1905 the Executive Council reports that it believes revocation to be a futile step; it suggests instead further conference. The Carpenters give notice that no quarter could be expected except through amalgamation with them. ${ }^{52}$ In 1906 the Executive Council reports no progress, and drops a tear for the innocent employer: by this time one union was treating, as unfair, shops having an agrec-

45. See p. 442 infra, for the Federation's unhappy experiences with this problem.

46. In 1889 the predecessor union of Woodworkers, the Furniture Workers, brotight essentially the same complaint before the convention. Proc. (1889) 34. In 1892 the Convention advised the two parties to negotiate claiming that because of principles of trade union autonomy it had no jurisdiction to decide. Proc. (1892) 34.

47. Proc. (1901) 252-3.

48. Proc. (1902) 52.

49. Proc. (1902) 166, 184-185.

50. Proc. (1903) 242-3.

51. Proc. (1904) 219.

52. Proc. (1905) 227. 
ment with the other. ${ }^{53}$ In 1907 the Convention learns that the rank and file of the Woodworkers had, on referendum, rejected amalgamation. At this the Convention begins to lose patience with the persistent little Woodworkers. It refuses to reindorse the award in their favor which only three years before it had approved. It recommends a further conference. $^{5 J}$ The dispute has now entered that stage so familiar in international politics where the stubborn little nation is "inciting" the big one. The Carpenters at the time had approximately 1800 votes in the Conrention, the Woodworkers 32. In 1909 the Committee on Adjustments reports a plan of amalgamation. If the Woodworkers refuse, their charter is to be revoked. They are damned if they do and damned if they don't. The secretary of the committee bases this brutal resolve upon the ironic dictates of justice typically appealed to in power politics:

"The Committee has come to the conclusion that where certain men in this labor movement do not see the benefit of concentration, we believe it is time to compel them to get into line for their own good."

The Convention allowed a decent interval for performing the sacrificial act. In 1912, after further threats, ${ }^{57}$ the Woodworkers amalgamated. ${ }^{\text {ts }}$ We are not concerned primarily with the justice of this settlement. It is more to our purpose that the dispute was settled. But even on the level of utility and efficiency, that it took twelve years to solve the problem detracts greatly from the achievement. Yet in one sense the Federation cannot legitimately be criticized for delay. In this case the only quick solution possible was an inequitable one. Where the Federation has persisted in maintaining a just decision in behalf of a weak against a strong union, it has had to sacrifice the objective of in fact settling the dispute or, at least, of settling it on terms announced by it. The Federation in 1917, in a dispute between the Flint Glass Workers and the Machinists, confirmed a voluntary arbitration award giving jurisdiction over glass molder-makers to the former ${ }^{50}$ It has tried often and again to assist the feeble Glass Workers in bringing the powerful Machinists to book. ${ }^{60}$ In 1919 Wharton of the Machinists, unabashed, asked why the Machinists should obey decisions when others did not; he said they would obey, if everyone else did. ${ }^{\text {II }}$ In 1931 the Executive Council was still seeking a solution. ${ }^{62}$ If the objective is the settlement of disputes on the best terms possible, it is at least questionable whether this rather Quixotic solution is preferable to the Machiavellism of the other. The case was, however, possibly more difficult to solve: whereas all V'ood-

53. Proc. (1906) 73, 208.

55. Proc. (1907) 270.

57. Proc. (1910) 289;

58. Proc (1912) 107.

60. Proc (1918) 293-297.

62. Proc. (1931) 433.
54. Proc (1907) \&2.

56. Proc. (1909) 291.

(1911) 322: this resolution practically revolked the charter.

59. Psoc. (1917) 124-125, 387-389.

61. Proc. (1919) 382. 
workers might find a logical basis of amalgamation with the Carpenters, the Glass Workers as a group, aside from the disputed ones, may have nothing in common with the Machinists; to take away even a small number from a union already small may make administration financially impossible.

Let us consider now that cause célèbre: the matter of the Brewery Workers against the Teamsters, Engineers, Firemen and Coopers. The Brewers received their charter in 1887, granting them jurisdiction over all brewery workers; the Teamsters received theirs in 1899, the Engineers in 1898, the Firemen in 1899. In 1899 the conflict between the Brewers, on the one hand, and the Firemen and Engineers, on the other, became acute. One delegate, protesting the claims of the Brewers, said that the Federation "might as well go on record as to whether it is an industrial organization or a trades union." ${ }^{3}$ The Convention authorized a committee of the Executive Council to deal with the case. In 1900 the Convention adopted a resolution confirming the Brewers' jurisdiction over "the employees of the brewery in the United Brewery Workers Union" provided that (a) craftsmen already organized in their own crafts were not to be molested but might voluntarily join the Brewers and (b) team drivers not working directly out of the brewery should go to the Teamsters' union. ${ }^{64}$ In 1901 a committee found that the Brewers were not respecting the decision of 1900 relating to the Firemen and Engineers. The Executive Council was authorized to settle the dispute and revoke charters upon non-compliance. ${ }^{65}$ In 1902 a committee decided that the 1900 decision gave jurisdiction of all craftsmen, except those already in craft unions, to the Brewers. But the Convention adopted a resolution that all craftsmen must belong to their respective unions. ${ }^{00}$ In 1904 the craftsmen were infuriated with the Brewers because they had secured injunctions against the craft unions. ${ }^{67}$ The Convention resolved that the Brewers should get the injunction dissolved and call off brewers who were scabbing in a plant struck by the Engineers and Firemen. ${ }^{68}$ In the same year a new settlement was resolved upon, confirming all present members to the Brewers, but providing that in the future craftsmen go to the craft unions and that there be joint boards in breweries where a majority of craftsmen were not represented by the Brewers. The Executive Council was to revoke charters on non-

63. Proc. (1899) 127.

64. Proc. (1900) 147-148.

65. Proc. (1901) 255. That part of the dispute relating to the Coopers has not been set out. See Proc. (1900) 147, 149; (1901) 127, 227, 245; (1902) 195; (1905) 228; (1914) 125.

66. Proc. (1902) 208.

67. In 1903 a formal resolution confirmed previous decisions Proc. (1903) 218, 219.

A Brewers' resolution "confirming" their charter was defeated. Proc. (1903) 249.

68. Proc. (1904) 228-229. 
compliance with this settlement. ${ }^{09}$ In 1905 the Council reported that none of the unions were complying and that it had hardly seemed sensible to revoke all the charters. ${ }^{70}$ The Convention reaffirmed the 1904 decision and admonished all affiliated national and local bodies "to exert every influence and power at their command to make the above decision operative and effective." 71 The Brewers objected to this resolution as inrolving "police methods."

Next year we hear that the injunction against the Firemen and Engineers is undissolved and the Convention again authorizes charter revocation. ${ }^{2}$ In 1907 the Executive Council actually revoked the Brewers' charter (a referendum among the Brewery workers rejected the 1904 award), but the Convention, apparently shaken by "a storm of protest . . . from . . . local unions and central bodies all over the country,"73 reinstated the charter and advised further conference with disciplinary action to follow. ${ }^{74}$ In 1908 the Brewers and Engineers agreed on a plan under which the Engineers were to keep their members, and those in the Brewers were to choose between the two unions. ${ }^{75}$ The Teamsters, on the other hand, tried to secure a reversal of the 1904 decision in so far as it awarded to the Brewers' drivers working out of the brewery. The Convention refused to reverse its decision. ${ }^{70}$ In 1910 the Convention was told that, of the engineers in the Brewers Union, 1092 had elected to stay, 62 to go to the Engineers. ${ }^{77}$ In 1911 the BreweryTeamster dispute broke out again in the soft-drink industry, ${ }^{78}$ and was referred to conference. In 1912 the Convention heard the quite familiar story that so far the parties had not been able to find a time to meet. ${ }^{70}$ In 1913 the Executive Council reported that since nearly all brewery teamsters were in the Brewery Union they should remain there. The Convention adopted the report. ${ }^{80}$ In 1914 we hear that the parties are still at a stalemate. ${ }^{81}$ And then for years after - until 1933 - there is a blessed silence. ${ }^{82}$ Apparently we are safe in believing that in 1915 there was a written agreement between the Brewers and Teamsters giving the brewery drivers to the Brewers and the soft drink drivers to the Teamsters. At least in 1933 when the conflict again broke out

69. Proc (1904) 217, 225-227.

71. Proc (1905) 223.

70. Proc (1905) 68.

73. Lorwin, The Amierican Feneration of Labor (1933) $93, \mathfrak{n}$. 21. This same Convention added Art. IX, $\$ 12$ to the constitution providing for revocation of charters by two-thirds vote of the Executive Council when authorized by a two-thirds majority vote of a convention.
74. Proc (1907) 275-277.
75. Proc (1908) 212
76. Proc. (1908) 213.
77. Proc. (1910) 105.
78. Proc. (1911) 331.
79. Proc. (1912) 117.
80. Proc. (1913) 105, 340.
81. Proc (1914) 401.

82. In 1914 a quarrel arose between the Brewers and the Carpenters. Proc. (1914) 418. An agreement entered into in 1915 [PRoc. (1915) 121] was confirmed by the Carpenters Convention in 1917. Proc. (1917) 128. 
in its present fury, the president of the Brewers produced such an instrument purportedly signed by $\mathrm{Mr}$. Tobin, president of the Teamsters. Mr. Tobin amazingly denied that he ever signed or heard of such a document. Yet it appears that in 1920 he referred to "an" agreement arguing that a case in point was not covered by it. ${ }^{83}$ Suffice it to say that in 1915, after 15 years of wrangling, this fight was settled for a time at least. The Brewers had far fewer votes than their much larger opponents, but won this act of the drama probably because they were first on the scene, and had built up enormous loyalty among brewery workers.

Then Prohibition came. The Brewery Union continued to pay the annual tax to the Federation on its membership. Whether it was real membership, the Federation did not too closely inquire. It was willing to sanction this benevolent fraud, if such it was, so that in the event of repeal, the union would be ready to take up its work again without break. In 1933 the Executive Council called the Brewers before it to show why all craftsmen who should work in the breweries, to be newly opened, should not go to their respective craft union. Wherewith the Council at once awarded the Engineers, Firemen and Teamsters to their respective unions, ${ }^{84}$ and notified all bodies to enforce the decision, prior to any Convention action. The break-neck speed of this decision must surely take away the breath of the reader, who if he has kept awake, must at least have been lulled into a settled expectation of unceasing conference. And what makes this haste even more startling is that the decision seems to reverse decisions which had been fifteen years in the making. The crafts argued that during Prohibition there had been little or no brewing, that the craftsmen in question had gone into their respective unions, and that thus it was no longer necessary to make an exception to craft jurisdiction in order to protect an existing industrial jurisdiction. ${ }^{85}$ The Convention confirmed the award. The Brewery Workers in a referendum promptly repudiated the award by a vote of 24,161 to 170 , but Mr. Green, president of the American Federation of Labor, pointed out that the wishes of the men were irrelevant. A union cannot determine its own jurisdiction. ${ }^{86}$ In 1934 the Convention, over the protest of the Teamsters, sent the matter to conference. ${ }^{87}$ In 1936 the conferences were still proceeding. ${ }^{88}$ And in the meantime the Teamsters and the Brewers were picketing and boycotting plants in which the other had agreements $;^{80}$ the brewery operators were uncertain as to which union was the representative of its men. Even though they

83. Proc. (1933) 339, 348.

85. Id. at 329-331.

87. Id. at 459 .

89. The Supreme Court of Washington has enjoined a secondary boycott by the teamsters Union of a brewery employing members of the Brewers' union. United Union

Brewing Co. v. Beck, et al., 5 LAB. REL. REP. 137 (Wash. 1939).
84. Proc. (1933) 115.

86. Proc. (1934) 144-152.

88. Proc. (1936) 200. 
should decide, then they might incur the punitive action of the rejected union.

The National Labor Relations Board, as we have seen, does not act in this type of case. One federal court has refused to give the Brewery Operators a declaratory judgment advising them with which union it should bargain collectively, on the ground the Federation is the final authority $;^{90}$ and more recently a federal court has reached the same result, but on the ground that the Labor Board has sole jurisdiction to make such a determination. ${ }^{01}$ In 1937 the Brewers Union unsuccessfully sought a direct review of the Federation ruling. ${ }^{92}$ Now it has again sought relief; at the present writing it has secured from the District Court of the District of Columbia an injunction. ${ }^{93}$ Certain of the Federationists, at least, intensely resent the action of the Brewers in appealing to the age-old enemy, the courts. ${ }^{04}$ Forty years in search of a forum: it would seem a sufficient concession to voluntarism.

The Federation has occasionally established formal tribunals for settling jurisdictional disputes. Such a tribunal has existed in one or another form in the Building Trades Department, a subsidiary body of the Federation composed of the building unions. Because of the great number of charters in the building trades, the arbitrary craft distinctions which they perpetuate, and the constant change of materials and process, jurisdictional disputes in this field are numerous and costly. Both of the recent indictments under the Sherman Act relate to disputes in the building trades. One of the unions concerned is the Carpenters. This union has been the particular bête noire of every attempt to establish an authoritative tribunal in the building trades. In 1909, only one year after affiliation with the department, the Carpenters refused to recognize its decision awarding to the Sheet Metal TYorkers the jurisdiction to erect metal trim. The department suspended them and asked the Federation to do likewise. This was the occasion for the usual speeches about the value of cooperation. The Federation refused ${ }^{95}$ and suggested the inevitable conference. The Carpenters then withdrew from the department. ${ }^{96}$ In 1915 they induced the department to reverse its decision and reaffiliated. ${ }^{97}$ They then deigned to confer for some 13

90. California State Brewers Institute v. Int'l Brotherhood of Teamsters, ctc, $19 \mathrm{~F}$. Supp. 824 (N. D. Cal. 1937).

91. Int'l Brotherhood of Teamsters v. Int'l Union of Brewery Workers, 5 LAJ. REL. REP. 112 (C. C. A. 9th, 1939) (note that this suit was brought by the Brewery Union whereas the prior suit was brought by the operators).

92. Proc. (1937) 125, 534-548.

93. N. Y. Times, Oct. 7, 1939, p. 10, col. 3.

94. Proc. (1937) 125, 542-3. N. Y. Times, Oct. 9, 1939, p. 11, col.1, Oct. 11, 1939, p. 21, col. 1.

95. Proc. (1911) 24, 339.

96. Proc. (1934) 360 .

97. Proc. (1934) 361. 
years with the Sheet Metal Workers; an agreement was reached in 1928.98 In 1918 the department set up a tribunal composed of representatives of labor, entrepreneurs and the building professions. This tribunal gave an award against the Carpenters and they promptly withdrew. In 1927 the department abandoned the board and its decisions against the Carpenters, who then graciously consented to reenter. In the meantime the Bricklayers had withdrawn in 1927 because of an adverse decision, and in 1929 the Carpenters again gained their freedom, this time because of a quarrel over dues. In 1931 they were joined by the Electricians who were opposed to the participation of employer representatives in settling jurisdictional disputes. ${ }^{90}$ These unions are the big three in the building trades and their state of mind and consequent defection substantially lessened the ability of the department to handle jurisdictional disputes. The department nevertheless gave decisions in cases involving them; it could breathe more easily when they were not inside the fold and whether they were in or out seemed to make little difference in their clisposition to accept decisions. In 1933 the big three clamored for readmittance because the department had been given a formal place in the Recovery Administration's Building Code. The department winced at the prospect of the return of these ruthless and prodigal sons and refused to readmit them. They feared particularly a coalition between them and a dissatisfied group of unions within the department. The officers of the Federation ordered the department to take them back. ${ }^{100}$ Upon refusal, the officers called a purported convention of the department, superseded the regular department convention, reinstated the unions and reorganized the department. The reorganized department then brought a suit in the District of Columbia for possession of the books and papers. This suit was lost on the ground that, though the Federation had complete authority over the department, the officers had exceeded their authority. The clear implication was that the officers might secure ratification at the next convention. The "regular" department unions must have seen the futility of their position. In 1935 they agreed upon a form of reorganization. ${ }^{101}$ Under the present constitution of the department, a permanent referee is appointed to settle disputes. ${ }^{102}$ It is too early to tell whether his decisions will command any greater respect than those of his predecessors.

The record of the Federation is not one of complete failure. Lorwin states that out of 207 jurisdictional cases reported between 1917 and

98. Proc (1916) 374-376; (1917) 127; (1918) 126, 277; (1919) 153; (1928) 69-70.

99. This story can be found in Proc. (1934) 152, 488 et seq.; LoRwin, THe AMerican Federation of Labor (1933) 378-383; Haber, Industrial Relations in tHe Building Trades (1932) 180-90.

100. Proc. (1934) 152, 488 et seq., 541.

101. Proc. (1935) 107-127, 327-342, 435-437.

102. PRoc. (1936) $600-602$. 
1931, the number dealt with decreased from 91 between 1917 and 1920 to 64 between 1921 and 1925, and 52 between 1926 and $1931 .^{103}$ From 1917 to 1931,80 new disputes arose but only 16 of these originated after 1925. ${ }^{104}$ Obviously, then, in this period some disputes were settled, and fewer new ones arose. This, however, was a period of increasing employment, a fact of particular advantage to skilled and organized labor. In the early part of the century, Gompers again and again lamented that the unions were unwilling ever to relinquish jurisdiction, so that the Federation's efforts were largely futile. In the twenties the reports of the Executive Council glow with recitals of a reckless cooperation which is shortly to make labor one happy family. ${ }^{105}$ In 1927 the Council reports five voluntary agreements. ${ }^{108}$ But, alas, in 1932 we find that the nine disputes before the Convention have gone into the endless treadmill of "conference," 107 and in the following year the confession is made that due to "unprecedented industrial depression and the terrible state of unemployment there was little that could be done" to settle jurisdictional disputes. ${ }^{108}$ It would be a rash or opinionated man who would or could draw any one conclusion from this history. The Federation's practice has in it much that is sound and representative of general political tradition. It emphasizes conciliation, discussion, compromise, consent - and infinite patience. It is often able to secure a solution truly voluntary. On a number of occasions, a weak union has been coerced to consent to an admittedly unjust decision by threats of revocation or hostile action. This is distressing to the lover of fair play, but it may be looked upon as the risk taken by the sheep when it enters the wolf's fold. It is futile to complain that the jurisdiction which on the whole is the best equipped to settle the question has decided it wrong, particularly when the parties have joined the association and submitted themselves to it. But there is legitimate cause to complain when it has failed over a considerable period of time to settle the question (a situation which we find to be not at all uncommon) and the disputants obstruct the efforts of the workers to determine a collective bargaining unit and of the employer to order his relations with his employees.

\section{The Courts}

In such cases as we have been describing, there is a quite legitimate demand for an authoritative forum which will delimit the area in which the jurisdictional dispute operates, by protecting third-party interests and

103. LoRwrn, op. cit. supra note 99 , at 342, n. 5 .

104. Lorwin notes also a great falling off after 1925 of building trade disputes and a revival again in 1929 . Id. at 381 .

105. Proc. (1927) 258; (1929) 75.

106. Proc. (1927) 44, 46-51, 389.

107. Proc. (1932) 79-82, 302-3, 409-22.

108. Proc. (1933) 290. 
allowing normal and effective labor relations despite the existence of the dispute. This does not mean that we should seek another fortum to settle the question of jurisdiction itself. Recently, indeed, the Brewery Union, whose story has been told in some detail above, has invoked judicial review of the decision of the Federation rendered against it in 1933. In the case of Obergfell $v$. Green, ${ }^{\mathbf{1 0 0}}$ an injunction was granted against the officers of the Federation and against the unions benefiting from that award. The Brewers claimed that the decision of the Federation was an unlawful interference with the contract rights represented by their charter jurisdiction. In this way they sought to avoid the force of rules which limit judicial interference with the activities of voluntary associations. The court upheld the Brewers' position. On a motion to dismiss the complaint, it ruled that the action of 1933 took from the brewery drivers "property rights of a substantial kind, probably the most important property right which unionized employees have . . . the action . . . transferring the brewery drivers . . . was entirely beyond the powers of the AFL, in that it violated the constitution of the AFL and the contract of the AFL" with the Brewery Union. ${ }^{110}$ In granting the injunction, the court said that if it withheld relief, it would amount to a "judicial recognition of authority acquired by usurpation." 111

On the other hand, two district courts in California have held (in this same controversy) that they are without jurisdiction to review the award of the Federation. ${ }^{112}$ In one of them, California State Brewers Institute v. International Brotherhood of Teamsters, et al., the court refused to advise the Brewery Operators as to the union to deal with. Treating the question as identical with the problem of charter jurisdiction (an inexact position, as I believe), it said:

"Decisions reached by labor unions according to their own constitution and by-laws of procedure are not to be invalidated by a court of law, provided that all parties have had an opportunity to be heard, that the decision has not been arbitrary, and that the fundamental law of the association has not been violated. A court of law will, therefore, not interfere with the decision of the American Federation of Labor, with its internal organization, or with the method of its making or enforcing its awards. The court recognizes the right of the American Federation of Labor to adjust jurisdictional disputes. The settlement of such controversies and the en-

109. 29 F. Supp. 589 (D. D. C. 1939).

110. Obergfell v. Green, 27 F. Supp. 934 (D. D. C. 1939).

111. Obergfell v. Green, 29 F. Supp. 589,592 (D. D. C. 1939).

112. California State Brewers' Inst. v. Int'1 Brotherhood of Teamsters, 19 F. Supp. 824 (N. D. Cal. 1937) and International Union of United Brewery Workers v. California State Brewers' Institute, 25 F. Supp. 870 (S. D. Cal. 1938). Note, however, that in the later case, the court enjoined all boycott action pending a settlement of the dispute. This decision has now been reversed. 106 F. (2d) 871 (C. C. A. 9th, 1939). 
forcement of such decisions is clearly the function of the Federation. That higher body to which these two labor organizations belong, and of which they are members, must determine this matter and render and enforce a binding decision between them, and agreements reached recognizing the American Federation of Labor decisions would be valid and binding on the parties should such agreements be reached." 113

Let us give brief consideration to the "property" concept invoked by the District of Columbia court as it bears on judicial control of the affairs of voluntary associations. ${ }^{11:}$ Individual members of trade unions, who have been expelled, have on occasion secured reinstatement by mandamus or injunction. The court may treat membership as a "contract" or "property" right arising out of the articles of association. In the usual case this will mean no more than that the member can demand that he be given a fair hearing prior to expulsion. ${ }^{115}$ As Professor Chafee has shown, this protection cannot be adequately explained on a theory of contract, particularly when procedural safeguards are implied by the court. ${ }^{116}$ There are cases where the substantial justice of the expulsion has been considered and where it has been set aside as contrary to "natural justice", "unauthorized" or "malicious." The by-laws of a trade union provided that any member using his influence against the legislative representative of the union should be expelled. A member petitioned the legislature for reconsideration of a law supported by the representative. His expulsion was held to violate his constitutional rights. ${ }^{117}$ A recent case protected a member against a change in seniority rules considered unjust. ${ }^{118}$ Cases of sheer malice, i.e., of expulsion for a reason not legitimately related to the purpose of the association, are extremely rare. In a recent Pennsylvania case, expulsion was achieved by dissolving the union, and organizing a new one which refused to admit the plaintiffs. The reasons for this action were obscure, the court found the "expulsion" to be malicious, ordered reinstatement and damages for loss of wages. ${ }^{110}$ Many courts, however, refuse to consider the merits if the trial has been

113. California State Brewers Inst. v. Int'l Brotherhood of Teamsters, $19 \mathrm{~F}$. Supp. 824, 824-5 (N. D. Cal. 1937).

114. Professor Chafee has given an admirable discussion of the attitude and conduct of the courts towards voluntary associations in his article, The Infenval Affairs of Associations Not for Profit (1930) 43 HARv. L. Rev. 993.

115. Metropolitan Baseball Club v. Simons, 17 W. N. C. 153 (Pa. 18s5), (1922) 7 CorN. L. Q. 262; Harman v. Raub, 25 Pa. C. C. Rep. 97 (1901); Taboada v. Sociedad Espanola de Beneficiencia Mutua, $191 \mathrm{Cal} .187,215$ Pac. 673 (1923); International Union of Steam and Operating Engineers v. Owens, 119 Ohio St. 94, 162 N. E. 386 (1923).

116. See Chafee, supra note 114 , at 1005.

117. Spayd v. Ringing Rock Lodge, $270 \mathrm{~Pa} .67,113$ Att. 70 (1921).

118. Fleming v. Mloving Picture Machine Operators, 124 N. J. Eq. 269, 1 Atl. (2d) 386 (1938).

119. Dorrington v. Manning, $135 \mathrm{~Pa}$. Sup. 194, 4 A. (2d) $\$ 86$ (1939). 
fair. Voluntary associations, they hold, are the arbiters of their own policies, their predilections and their antipathies. ${ }^{120}$ The "contract" or "property" concept is an artificial device to protect the helpless individual member in preserving an association without which he may not be able to secure work in his trade. It is a recognition of this need, rather than any necessary legal consequence arising from the form of the transaction, which justifies the courts which do grant relief to trade union members.

The type of case involving the power of a national union over its chartered locals is more germane. Most of these cases involve the funds of dissolved or suspended locals. There is a strong disposition to regard the members of the local as having an interest in the funds inclependent of national affiliation. In the absence of a specific charter provision, it may be held that a majority of the local members do not lose control of the funds despite charter revocation or a decision of the superior body in favor of a minority. ${ }^{121}$ But most courts will recognize the claim by the superior body if based on specific contract. ${ }^{122}$ Even so, the charter must provicle a fair method of hearing ${ }^{123}$ and the procedure must be followed. ${ }^{124}$ An occasional court may add that the revocation must be

120. State v. New Orleans Funeral Directors Ass'n, 161 La. 81, 108 So. 132 (1926); Long v. Baltimore \& O. R. R., 155 Md. 265, 141 Atl. 504 (1928); International Union of Steam \& Operating Engineers v. Owens, 119 Ohio St. 94, 162 N. E. 386 (1928).

121. Wicks v. Monihan, 130 N. Y. 232, 29 N. E. 139 (1891).

122. Fidelity \& Deposit Co. v. Brotherhood of Painters, 120 N. J. Eq. 346, 184 Atl. 832 (1936). Contra: State Council v. Enterprise Council, 75 N. J. Eq. 245, 72 Atl. 19 (1909). Cf. Lumber \& Sawmill Workers Union v. Int. Woodworkers of America, 197 Wash. 491, 85 P. (2d) 1099 (1938); Local v. Cairns, 197 Wash. 476, 85 P. (2d) 1109 (1938); Local v. Taylor, 197 Wash. 515, 85 P. (2d) 1116 (1938); Harris v. Backman, 86 P. (2d) 456 (Ore. 1939). All these involved the quarrel between the CIO and the AFL (Carpenters Union) concerning the affiliation of sawmill workers. In all cases, the overwhelming majority of members of the AFL locals voted to go over to the CIO. The local charters provided that as long as ten members remained, the locals should continue to exist. All decisions held that AFL locals were entitled to the funds. In the Washington cases, three judges dissented. (See cases infra note 165 relating to the intervention of the NLRB and the courts in other phases of this controversy). Accord: Low v. Harris, $90 \mathrm{~F}$. (2d) 783 (C. C. A. 7th, 1937). In these decisions the courts refused to hold that funds raised in addition to those required by the national body were to be distinguished and treated as "belonging" to the "local association" and so controllable by the majority. Some courts, however, have adopted this theory for local benefit funds, at least in the absence of a very explicit charter statement to the contrary. Scott $v$. Donahue, 93 Cal. App. 126, 269 Pac. 455 (1928), following State Council v. Emery, 219 Pa. 461, 68 At1. 1023 (1908) (emphasizing the idea that trust funds must be devoted to the intended purposes).

123. Neal v. Hutcheson, 160 N. Y. Supp. 1007 (Sup. Ct. 1916) (suspension under a by-law permitting the national president to act without hearing invalid).

124. Harris v. Geier, 112 N. J. Eq. 99, 164 At1. 50 (1932) (district council cannot take over funds of local without following prescribed procedure). Schweitzer v. Schneider, 87 N. J. Eq. 88, 97 Atl. 159, aff'd, 86 N. J. Eq. 256, 98 At1. 1086 (1916) (national 
"for cause," but does not make it clear whether this implies more than a requirement of fair hearing. ${ }^{125}$ However, in these cases the "property" claim in the conventional sense is strong and real. In a rare case such as Musical Mutual Protective Union v. I'cber, ${ }^{120}$ there arises the question of the right to the charter itself. Though the court said that the local had a "perfect right to govern its own internal affairs," in matters concerning affiliation it is subject to the discipline of its superior body. ${ }^{12 \pi}$ The case, however, does not prove much, since the prescribed procedure had been followed and the local had clearly violated a binding rule.

It is doubtful that there is any such justification, as there is in the member cases or in the local cases involving funds, for judicial control of the decisions of the Federation on charter jurisdiction. Two previous appeals to the courts to review the AFL award in the Brewers' case have met with refusal. ${ }^{128}$ These seem to be the only cases directly in point. A rather frivolous analogy concerned the revocation of the charter of a local chapter of a college sorority. The girls, it seems, were not the right sort for their more exalted sisters on other campuses. This grave issue raised in two companion cases divided the courts of $\mathrm{New}$ York ${ }^{129}$ and Massachusetts, ${ }^{130}$ which found, respectively, that "contract" rights were and were not invoked, the New York court going on to find the expulsion unauthorized by the rules. But the claim that charter jurisdiction is a "property" or "contract" right, even if verbally plausible, is too unreal a consideration to determine whether the courts are an appropriate forum to review Federation decisions. It has been previously pointed out that one of the difficulties of deciding these disputes has been the impossibility of formulating controlling rules of judgment. The process is one of compromising irreconcilable claims, of creating a solution out of a complex of faulty definitions. disputed priorities and ineluctable shifts in industrial process and history.

In Watson v. Jones one faction of the local congregation of the Presbyterian church was suing for church property. ${ }^{131}$ The general assembly of the church had decided in favor of this faction. The losing faction claimed that in matters involving property the courts were the final judges

union split into two factions, great majority of local support one faction; held entitled to funds).

125. Scott v. Donahue, 93 Cal. App. 126, 127, 269 Pac. 455, 457.

126. 123 Misc. 182, 205 N. Y. Supp. 599 (Sup. Ct. 1924). Cf. Taussig v. Weber, 123 Misc. 180,205 N. Y. Supp. 605 (Sup. Ct. 1924).

127. 123 Misc 182, 188, 205 N. Y. Supp. 599, 604.

128. California State Brewers Inst. v. Int'l Brotherhood of Teamsters, 19 F. Supp. \$24 (N. D. Cal. 1937), Proc. (1937) 534-548.

129. Heaton v. Hull, 28 Misc. 97, 59 N. Y. Supp. 281 (Sup. Ct. 1899), aff'd, 51 App. Div. 126, 64 N. Y. Supp. 279 (3d Dep't 1900).

130. Heaton v. Richmond, 42 Axr. L. Rev. 178 (Mrass. 1900).

131. 13 Wall. 679 (U. S. 1871). 
of the meaning of the church's constitution. The issue, they argued, was "whether the church in relation to its civil interests is organized under the authority of law or above it." 132 The Supreme Court, Mr. Justice Miller speaking, refused to review the determination of the assembly. He admitted that the English courts, following Lord Eldon, had set themselves up as arbiters of church law. We can understand, said he, that the Lord Chancellor of England who is the head and representative of the established church and who controls very largely the church patronage "should feel, even in dealing with a dissenting church, but little delicacy in grappling with the most abstruse problems of theological controversy or in construing the instruments which those churches have adopted as their rules of government or inquiring into their customs and usages. The dissenting church in England is not a free church in the sense-in which we apply the term in this country . . ."133 But such, he said, should not be the rule in this country. ". . . It is easy to see that if the civil courts are to inquire into all these matters, the whole subject of the doctrinal theology, the usages and customs, the written laws, and fundamental organization of every religious denomination may, and must, be examined into with minuteness and care, for they would become, in almost every case, the criteria by which the validity of the ecclesiastical decree would be determined in the civil court. This principle would deprive these bodies of the right of construing their own church laws, would open the way to all the evils which we have depicted as attendant upon the doctrine of Lord Eldon, and would, in effect, transfer to the civil courts where property rights were concerned the decision of all ecclesiastical questions." 134

It is doubtful that the criteria for judging disputes within unions should be or could be reduced to standards manageable in a court of law. Reference to the Brewers' case, though it may convince one of the likelihood that injustice will be done by the Federation, will equally convince that it is hopeless to appeal to the law of property or contract to find a solution unless, indeed, one is prepared to say that the words of the charter are the sole relevant determinative of decision. If that is the contention of the Brewers, then it implies, as was stated by the Council, that the Federation is without power or authority to deal "with ever changing scenes and quite regardless of conflicts between affiliated unions and disastrous consequences affecting the labor movement as a whole." Professor Chafee has put the matter excellently: "Legal supervision must

132. Id. at 703. Cf. the language of Goldsborough, J., in Obergfell v. Green, $29 \mathrm{~F}$. Supp. 589, 592 (D. D. C. 1939) : “. . . whenever usurped authority comes in contact with the jurisprudence of a democracy it then and there, instantly, ceases to exist."

133. Watson v. Jones, 13 Wall. 679,728 (U. S. 1871).

134. Id. at 733.

135. PROC. (1937) 125. 
often be withheld for fear that it may do more harm than good. The principle of freedom and growth is easily overlooked by judges. They are apt to regard the documents with which the association starts its existence with the same strictness as if they were private contracts or trusts . . . The consequence of this judicial interference is, that if these original documents lack workable provisions for their own alteration, then the association is denied the power to adapt itself to inevitable changes in its environment." 130

The whole practice and history of the Federation demonstrates that paper claims to jurisdiction are recognized as only a starting point or prima facie case. The charters of the associated unions appear to represent a modus vivendi, a voluntary arrangement whereby they can live and work together. In Cherokee Indians ${ }^{\prime}$. Georgia, ${ }^{13 \pi}$ the Supreme Court was asked by the Cherokee Indians to declare as against the State of Georgia their sole jurisdiction over their tribal lands. This claim they based on a treaty with the United States. MIr. Justice Johnson, denying in his usual forceful and emphatic manner the existence of a justiciable issue, said, "The contest is distinctly a contest for empire. It is not a case of meum et tuum in the judicial but in the political sense. Not an appeal to laws but to force. There is then a great deal of good sense in the rule laid down in the Nabob of Ascot's case, to-wit, that as between sovereigns, breaches of treaty were not cognizable in a Court of Justice."138

Unless mistaken in my understanding of the nature of the issues involved and of the method in which they are settled, it follows that such decisions are not the subject of legal judgment. The members of the Federation have surely been aware of this. They have witnessed decisions flagrantly unjust. They have known that in a body political in nature decisions may often be political. They have understood that if they did not like a decision, they might leave. ${ }^{130}$ The recent action of the District Court of the District of Columbia in granting the Brewers an injunction against the execution of the 1933 award ${ }^{140}$ is apparently the first such action in our courts. ${ }^{141}$

136. Chafee, sipra note 114, at 1027-1028.

137. 5 Pet. 1 (U. S. 1831).

138. Id. at $28,29$.

139. Compare the following remarks in course of the 1937 debate: "If the claim be sound that affliation to the American Federation of Labor involves a property right subject to review, regulation and control by our equity courts then indeed will the whole structure of American allied or federated trade unionism and of voluntary relationship be placed in jeopardy." Proc. (1937) 125.

140. Obergfell v. Green, 29 F. Supp. 589 (D. D. C. 1939).

141. A very interesting example, showing how ancient is the problem, of judicial determination of craft-jurisdiction comes from the pre-Revolutionary Mfayor's Court of New York. The court, in 1674, ordered the brewers and bakers to allow the corn and wine 
Our courts have not, however, been at all shy in enjoining picketing or boycott of an employer who has contracted with or employs members of a rival union. For some of them, at least, it is enough that the objective is a closed shop ${ }^{142}$ for others, that it seeks to induce a breach of contract $;^{143}$ for others, that the pickets are not employees ${ }^{144}$ - all three concurring provide a feast of reasons. In contrast is the courageous decision in the famous case of Stillzvell $v$. Kaplan. ${ }^{145}$ An employer, having a closed shop agreement with a union, was picketed by a rival. Said Chief Judge Pound:

"We would be departing from established precedents if we upheld this injunction. We would thereby give to one labor union an advantage over another by prohibiting the use of peaceful and honest persuasion in matters of social rivalry. This might strike a cleath blow to legitimate labor activities. It is not within the province of the courts to restrain conduct which is within the allowable area of economic conflict." 146

Successfully to fulfill its purpose, labor needs vigorous, honest, representative unions. The existence of a contract with a union is no assurance that these objectives have been fulfilled. An employer may find it to his advantage to protect himself from effective union activity by an unholy alliance with a corrupt or dominated union. The court has no mechanism for distinguishing between unions. Consequently, it must suffer the process of selection to proceed by picket which may be the only available instrument. If a bad union wins or an employer is injured in the process, this is no more than may happen in any field in which democracy and laissez-faire are accepted. This is the philosophy of Stillzoell $v$. Kaplan, and since the advent of the anti-injunction acts which

porters, rather than the day laborers, to carry their goods. This probably did not involve review of a prior decision of any adjudicative body. Griffith, History of AMsericaN City Government (1938) 138. The author is indebted to his colleague, Dean Mark DeWolfe Howe, for this reference.

142. Keith Theatre v. Vachon, 134 Me. 392, 187 Atl. 692 (1936); Yankec Network v. Gibbs, 3 N. E. (2d) 228 (Mass. 1936) ; Carter Sample Furniture House v. Retail Furniture Employees Local, 122 N. J. Eq. 575, 196 Atl. 210 (1937); Stalban v. Friedman, 171 Misc. 106, 11 N. Y. Supp. (2d) 343 (Sup. Ct. 1939); McKay v. Retail Automobile Salesmen's Union, 4 LAB. Ret. ReP. 356 (Cal. 1939).

143. Hitchman Coal Co. v. Mitchell, 245 U. S. 229 (1917); International Organization, United Mine Workers of America v. Red Jacket Consolidated Coal \& Coke Co., 18 F. (2d) 839 (C. C. A. 4th, 1927), cert. denied, 275 U. S. 536 (1927); Goyette v. Watson Co., 245 Mass. 577, 140 N. E. 285 (1923) ; Kraemer Hosicry Co. v. American Federation of Full Fashioned Hosiery Workers, 305 Pa. 206, 157 Atl. 588 (1931).

144. Armstrong Cork \& Insulation Co. v. Walsh, 276 Mass. 263, 177 N. E. 2 (1931); United Electric Coal Co. v. Rice, 80 F. (2d) 1 (C. C. A. 7th, 1935), cert. denied, 297 U. S. 714 (1936) ; Newton v. Laclede Steel Co., 80 F. (2d) 636 (C. C. A. 7th, 1935); Scavenger Service Corp. v. Courtney, 85 F. (2d) 825 (C. C. A. 7th, 1936).

145. 259 N. Y. 405,182 N. E. 63 (1932).

146. Stillwell v. Kaplan, 259 N. Y. $405,412,182$ N. E. 63,66 (1932). 
forbid courts to enjoin picketing where there is a "labor dispute," courts which would formerly have granted an injunction have had to follow Stillwell $v$. Kaplan, ${ }^{147}$ unless they are prepared to hold that a jurisdictional dispute is not a "labor dispute." 148

The result of Stillwell $v$. Kaplan may, however, be harsh, expensive and wasteful in particular cases. An electoral campaign which did not cease after there had been an adequate time to test issues, a civil war which did not contain within itself the germs of resolution, would be futile and exasperating. The economic conflict which the case tolerates may carry the parties to exhaustion rather than to a decent or even to any solution at all. This we have seen can be true even if both of the unions are members of the Federation, and it may be even more true where they are not.

\section{The Labor Bohrds}

The procedure of the labor boards suggests the possibilities of a positive solution. ${ }^{149}$ The National Labor Relations Board is authorized to determine a collective bargaining representative by ascertaining the will of a majority of the workers in an appropriate bargaining unit. We have seen, however, that the Board so far has refused to take jurisdiction where the question of representation arose out of a dispute between unions subject to the authority of a common federation. I repeat that the determination of a representative does not by its terms settle a jurisdictional dispute. As a result of elections in plant $A$, a driver may find that he is represented by the Brewers Union, and in plant $B$ by the Team-

147. Fur Workers Union v. Fur Workers Union (1939) 7 U. S. L. WeEk 698, aff'g, 105 F. (2d) 1 (App. D. C. 1939) ; J. H. \& S. Theatres v. Fay, 260 N. Y. 315, 183 N. E. 509 (1932) ; Cinderella Theatre Co. v. Sign Writers' Union, 6 F. Supp. 164 (E. D. Mrich. 1934) ; Levering \& Garrigues Co. v. Morrin, 71 F. (2d) 284 (C. C. A. 2d, 1934), cert. denied, 293 U. S. 595 (1934) ; Edjomac Amusement Corp. v. Empire State Motion Pieture Operators' Union, $273 \mathrm{~N}$. Y. 647, 8 N. E. (2d) 329 (1937).

148. United Electric Coal Co. v. Rice, 80 F. (2d) 1 (C. C. A. 7th, 1935), ccrl. denied, 297 U. S. 714 (1936) ; Newton v. Laclede Steel Co., 80 F. (2d) 636 (C. C. A. 7th, 1935). Cf. Stalban v. Friedman, 171 Misc. 106, 11 N. Y. S. (2d) 343 (Sup. Ct. 1939) Cotillo, J., holding that Stilla'ell a. Kaplan should no longer be applied, despite passage of State anti-injunction act (N. Y. CIv. Prac. ACT \$876-a) because of protection now afforded to labor by the State Labor Act.

Mayor LaGuardia has announced that he would not tolerate "indiseriminate" pick:eting in jurisdictional disputes. The situation involves "cross-picketing" i.e., for each AFL shop picketed by a CIO union, the AFL pickets a CIO shop. It is not clear whether the Miayor's refusal to "tolerate" means that he will have pickets dispersed or arrested. The Miayor feels his position is not inconsistent with the Norris-LaGuardia Act. N. Y. Times, Dec 8, 1939, p. 1, col. 3. His announcement was attacked as a "usurpation of power." N. Y. Times, Dec. 9, 1939, p. 1, col. 2, p. 11, col. 3.

149. See Comment (1938) The Influence of the National Labor Relations Board uthon Inter-Union Conflicts, 38 CoL. L. REv. 1243, for an able and comprehensive survey of the materials on this subject. 
sters Union. This may be true because in plant $A$ there has been no prior history of craft organization and the Board decided that the employees constitute a single unit for collective bargaining, or it may be the drivers themselves may wish to have a representative common to the whole plant. Now, to be sure, decisions of this sort, which give rise to the possibility that the structure of collective bargaining in particular plants will cut across national charter jurisdictional lines, which in other words allow drivers in one plant to be represented by the Teamsters Union and in another by the Brewers Union may indirectly break down the strength of a national union, may bring pressure on the Federation to bring out some solution. In so far, too, as national solidarity among similar workers is valuable to the worker, the result of this atomization may be harmful. This is a sufficient reason why the Board should be cautious in entering such disputes. But where the Federation has been unable within a decent interval - let us say two years - to bring the parties together, and where the parties interfere with any attempt by employers and employees to find pro tem a basis of operation, the balance, I believe, is decidedly in favor of Board intervention. Such action seems superior to resort to the Sherman Anti-Trust Act or repressive anti-picketing statutes.

We have already referred to the attempt of the Brewery Institute to secure a declaration from the federal court in California as to which of the rival unions was the proper representative for collective bargaining. The Brewers based their appeal principally on the fact that the Board refused in such cases to take jurisdiction. As we have seen, the court declined jurisdiction on the ground that it would not review action of the Federation. ${ }^{150}$ It maintained, furthermore, that the Board was right in taking the same position. But in a more recent phase of the controversy, the Circuit Court of Appeals for the Ninth Circuit has declared emphatically that the Board does have and must exercise jurisdiction to determine a collective bargaining agency regardless of the fact that the occasion for the determination is an intra-Federation dispute. ${ }^{151}$ The district court, at the suit of the brewery workers, had declared that the Brewery Union was the bargaining agent for the brewery deliverymen in California, Oregon and Washington. The circuit court of appeals reversed the decision and ordered the action to be dismissed. The Board,

150. California State Brewers Institute v. International Brotherhood of Teamsters, 19 F. Supp. 824 (N. D. Cal. 1937).

151. International Brotherhood of Teamsters v. International Union of Brewery Workers, 106 F. (2d) 871 (C. C. A. 9th, 1939). The court argues that the Board has not been relieved by Congress because the unions by their private arrangement with the Federation are subject to its jurisdiction. Here is a case of violent and widespread controversy. Both the men and the employer are entitled to relief. Though the Board has discretion as to whether it will entertain a representation proceeding, it is a "legal" discretion. 
it held, had jurisdiction which, under the familiar rule, must be exhausted before a court could intervene. ${ }^{162}$

I can well understand that the Board hesitates to enter these cases, though it probably "has jurisdiction." 153 There is nothing in the debate or the committee reports on the Act bearing directly on the issue, but the power to determine units and to hold elections is stated to be similar to that of the Railway Mediation Board. ${ }^{15 s}$ This Board has, reluctantly, held elections in cases precipitated by jurisdictional disputes. ${ }^{155}$ The power probably exists, but its exercise is politically dangerous. The Federation has indicated its opposition to Board jurisdiction and seeks to amend the Act specifically to exclude jurisdiction in such cases. ${ }^{150}$ The Federation members would much rather fight among themselves than see the control of these issues, no matter on what level, go to an outside authority, particularly a government organ. Furthermore the elective process which the Board must use puts the question to the rank and file. We have seen that when the brewery workers decided by' a nearly unanimous vote to remain or go into the Brewery Union, President Green said that the wishes of the workers were immaterial. The New York Labor Relations Act specifically forbids the state board from intervening in such a matter. ${ }^{157}$ The NLRB is fighting now on many fronts. It has earned particularly the enmity of the AFL and recently of the CIO, and might find its position more intolerable still, were it to change an established rule in the face of that hostility. It is, perhaps, then a case where Congressional action is necessary. The Federation seems determined to oppose a specific grant of power orer these disputes though it should realize that the result of opposing a deliberate solution is to provoke the application of very bad solutions.

It may be, of course, that neither union is willing to risk a show of strength in which case the employer is (where Stillacell $"$ '. Kaplen is law) without remedy, unless he may set in motion the machinery of

152. Id. at 876 .

153. Comment (1938) 38 CoL. L. Rev. 1243, 1245, states that the NLRB "clearly has the power to intervene in disputes over representation of workers between unions affiliated with a common body."

154. Sen. Rep. No. 573, 74th Cong., 1st Sess. (1935) 14; H. R. Rep. No. 972, 74th Cong., 1st Sess. (1935) 20.

155. The authorities for this are collected in Comment (1938) 3S CoL L. REw. 1243, $n$. 5, 1245, n. 16. S. 3266, 73d Cong., 2d Sess. (1934) to amend the Railway Labor Act provided for "neutral" boards to determine who should vote in order that antipathy created by the determination not be directed against the Board itself. SErr. Rep. No. 1065, 73d Cong., 2d. Sess. (1934). This bill was not the basis of the Act finally passed.

156. Proposed amendment to $\S 9$ (c) of the Act included a provision that the Board shall not have jurisdiction to investigate any question or controversy between individuals or groups within the same labor organization or affliated with the same parent organization. (1939) 3 LAB. REI. REP. 674.

157. N. Y. LABOR LAW $\$ 705(3)$. 
the Board. In a capitalist society where nothing runs unless the entrepreneur runs it or is permitted to run it, the employer represents in cases of this sort a legitimate social interest. Until recently the National Labor Relations Board has not permitted employer petitions seeking a determination of a representation dispute. The danger of such petitions are, indeed, considerable and quite obvious. If the employer may petition as a matter of right, he can do so at the first threat of unionization and force his employees to elect against an outside union or for a company union before they understand the issues or have been laid open to persuasion. The Board, however, has discretion in any case in entertaining jurisdiction. It has recently capitulated to the terrific pressure of the forces hostile to it and its rules now permit employer petition. ${ }^{168}$ The same is true by law in Minnesota, ${ }^{150}$ New York, ${ }^{160}$ Pennsylvania, ${ }^{101}$ and Wisconsin. ${ }^{162}$ In New York the Board may entertain such a petition, ${ }^{103}$ but can only proceed to final action on it if at least one of the unions consents. ${ }^{164}$

One problem remains. In the famous fight between the Carpenters Union (AFL) and the Woodworkers (CIO) in Oregon, the Board held an election which the CIO won. ${ }^{165}$ The Carpenters treated the results of the election as irrelevant. ${ }^{160}$ They and their associate unions, by picket and boycott, held up a good part of the lumber business for some period of time. The public was angry and frantic, and the experience provided a plausible occasion for enacting one of the most reactionary of existing anti-picketing laws.

In the Star Publishing Company case, a newspaper was threatened by the Teamsters Union with a boycott if certain of its employees did not become members. ${ }^{167}$ The employees were loyal to the Newspaper Gtild.

158. N.L.R.B. Rules and Regulations, Art. III, $\S 1$.

159. Minn. Labor RelatTons ACT, §16(b).

160. N. Y. LABOR LAW, $\S 705(3)$, (4).

161. Pa. LABor Relations Act, $\S 7$ (c) allows a petition by an employer "who has not committed an unfair labor practice."

162. Wis. Employment Peace Act, $\S 111.05(4)$.

163. N. Y. LABOR LAw, § 705(4).

164. In the first two months after the NLRB amended its rules to allow employer petitions, 16 employers appealed for elections, representing 4 percent of the total of 400 petitions presented to the Board during that period. The New York Board has reported 85 employer petitions out of a total of 2581 petitions received over a period of 2 years, and 52 of these were occasioned by disputes where two or more unions were involved. (1939) 5 LAB. REL. Rep. 41.

165. Jones Lumber Co., 3 N.L.R.B. 855 (1937), (1937) 1 LAB. Ret. ReP. 220.

166. (1937) 1 LAB. REL. REP. 331.

167. 4 N.L.R.B. 498 (1937). Other cases where the Board ordered the employes to recognize one union in the face of threats of picketing and boycott by a rival union are Pittsburgh Plate Glass Co., 4 N.L.R.B. 193 (1937) ; Peninsular \& Occidental S. S. Co., 5 N.L.R.B. 959 (1938); Simmons Co., 6 N.L.R.B. 208 (1938). 
They refused to join the Teamsters Union and were discharged. The NLRB admitted that the position of the employer was "unenviable" and that if it were forced to reinstate these employees it might be unable to operate its newspaper. But it held (quite properly) that the discliarge interfered with the statutory right freely to choose representatives for collective bargaining. ${ }^{108}$ Under the competitive regime represented by Stillwell $v$. Kaplan, the employer was as free as was his employees to choose the stronger union. The National Labor Relations Act takes from him this choice. It puts the processes of law in the place of a balder economic conflict. But if it compels the employer to recognize a union too weak to protect him from a rival's deadly boycott and yet gives him no legal substitute for his freedom, it may provoke legitimate resentment. The boycott makes a mock both of the employer who is told that his employees' choice is none of his business and of the employees whose choice becomes the occasion for a stoppage of work.

At least one court has enjoined ${ }^{168}$ activity by a union defeated in a Board representation proceeding; and recently some, at least, of the Supreme Court judges have in the course of argument indicated that they would do that. The Norris-LaGuardia Act forbids injunction in labor disputes. If it is granted that a jurisdictional fight is a labor dispute, does it cease to be one because the Board has certified a representative in a particular unit? It has been argued above that the Board's decision does not settle the jurisdictional dispute as such. It is said, however, that picket and boycott after certification interfere with the right of the majority to choose a representative which under the Act becomes the exclusive representative, and that there is an implied repeal of the Norris-LaGuardia Act. It is said, furthermore, that the minority is asking the employer to violate his statutory duty to bargain solely with the majority. It should not be overlooked, however, that the Act preserves the right to strike. ${ }^{170}$ From this it may be argued that the Act does not outlaw the economic weapons of labor, and if we accept Stillicell v. Kaplan, we recognize that strikes and picketing are legitimate instruments whereby a minority or even outsiders may seck to win over the workers to their union, so that the minority will become the majority. It is true that the need for these weapons is no longer so urgent. The

168. N.L.R.B. v. Star Publishing Co., 97 F. (2d) 465 (C. C. A. 9th, 1938).

169. Oberman \& Co. v. United Garment Workers, 21 F. Supp. 20 (W. D. Alo. 1937). Cf. Stalban v. Friedman, 171 Misc. 105, 11 N. Y. S. (2d) 243 (1939), where N. Y. State Labor Board said there was no question that the contracting union represented employees and so refused to certify; an injunction against the outside union was granted.

170. Professor (Judge) Magruder suggests that as the statute imnoses unon the cmployer the duty to bargain with the unit designated by the Board, a strike to compel him to violate this duty may be held illegal as a matter of common law. Magruder, $A$ Half Century of Legal Influence upon the Derelopment of Collectize Bargaining (1937) 50 HARV. L. REv. 1071, 1107. 
machinery of the Board provides a formal process through which rival claims may make their appeal. That, of course, would not be so if the Board accepted jurisdiction prematurely; but to date at least the Board has been well aware of this danger. Furthermore the certification does not preclude a new election after the lapse of a reasonable time, possibly a year, even though the successful union negotiates a contract for a longer period. ${ }^{171}$

But on the whole, it is at least doubtful whether the Wagner Act works a repeal pro tanto of the Norris-LaGuardia Act. ${ }^{172}$ In the course of the Congressional debates on the Act, Senator Walsh, in reply to an objection that the majority rule might be unfair to minorities, said: "any agreement arrived at with the majority representatives is applicable to all the workers in the unit. If a dissenting minority do not like the terms of the agreement, there is nothing in the bill which prevents the minority from quitting or striking." 173 Moreover, an amendment was offered in the House to the effect that, though nothing in the Act should impair the right to strike, a strike after an agreement made between an authorized majority and its employer should be considered "as a violation of the spirit of this act." ${ }^{174} \mathrm{Mr}$. Connery, the sponsor of the bill in the House, said that this amendment would take "the heart right out of the bill." 175 The amendment was lost. ${ }^{178}$

Professor Robert R. R. Brooks in his recent and excellent book, Unions of Their Own Choosing, opposes any amendment of the law permitting the use of the injunction against the activities of defeated minorities:

"Injunction law has not succeeded in the past in inducing industrial peace. The Norris-LaGuardia Act marked a recognition of this fact. The NLRA (sic) went further by substituting administrative handling of human relations in industry for judicial repres-

171. Metro-Goldwyn-Mayer Studios, 7 N.L.R.B. 662 (1938); Columbia Broadcasting System, Inc., 8 N.L.R.B. 508 (1938). The New York Board has adopted a rule that its certification will be conclusive for one year: N.Y.L.R.B., Preliminary Rules and Regulations, Art. III, §11.

172. In Lund v. Woodenware Workers Union, 19 F. Supp. 607, 610 (D. Minn. 1937), the court states: "That Congress did not intend to limit in any way the actions of the minority in protesting against the agreements of the majority and generally in taking legal measures by strike to achieve redress of alleged grievances, is sustained by the provision of $\$ 163,29$ U.S.C.A., which reads: 'Nothing in this chapter shall be construed so as to interfere with or impede or diminish in any way the right to strike.' The court leaves open the question of whether it has jurisdiction to enjoin interference with an agreement between an employer and a representative certified by the Board."

And see the discussions in Grace Co. v. Williams, 20 F. Supp. 263, 267 (W. D. Mo. 1937), aff'd, 96 F. (2d) 478 (C. C. A. 8th, 1938) ; and in Cupples Co. v. American Federation of Labor, 20 F. Supp. 894, 897-900 (E. D. Mo. 1937).

173. 79 CoNg. Rec. 7672 (1935).

174. Id. at 9730 .

175. Ibid.

176. Ibid. 
sion. The advantages of the administrative process lies in its flexibility, in the expertness of administrators in their specialized field, and in the general concept of removing the cause of trouble rather than suppressing the result. The leaders of organized labor will be short sighted indeed if, by refusal to accept the board's decision in inter-union conflicts, they provoke legislative reaction." 177

This uneasy argument contains, I believe, the germs of contradiction. Mr. Brooks believes that the administrative procedure with its specialization and flexibility is the appropriate method of settling such disputes. Well, by hypothesis, the dispute has been settled by that method. The question then is whether the Board's action shall be made operative in the face of opposition. Mr. Brooks' argument seems further to imply that an injunction would not in any case be effective because injunetions have not in the past brought industrial peace. But as I have pointed out, in the past labor was without the protection now afforded by the labor acts. An injunction based on a determination of the Labor Board is very different from an injunction which is part and parcel of a general system of repression. Mr. Brooks concludes by abjuring labor leaders to be reasonable lest they provoke reactionary measures. But history shows that it is not unusual for rival labor leaders each to insist that the reasonable thing is for his rival to capitulate. In such cases they cannot be led to believe that they are responsible for any reaction which may occur. We are faced then with a problem of whether it is worthwhile to solve a situation which time has demonstrated cannot be settled by statesmanlike voluntarism, foresight and goodwill. Yet there is this to be said for Mr. Brooks' position. First: In most cases the decision of the Board is accepted. Second: jurisdictional and inter-union disputes are a relatively minor cause of strikes rarely exceeding eight percent of the whole number, and consisting on the average of only between five and six percent. ${ }^{178}$ The extent then, to which the productive forces of the country are impeded by them has been exaggerated. These facts are particularly relevant if an amendment permitting an injunction may be dangerous. And I think it is not without risk. The danger would be primarily symbolic. The amendment would propagate the fear and the hope that

177. Brooks, Unions of Their Own Choosing (1939) 167.

178. The Bureau of Labor Statistics divides inter-union disputes into "jurisdictional" (intra-Federation) and rival union (dual unions). For 1937 these two sources accounted for 3.7 percent of the number of strikes, 4.5 percent of workers involved in strilke, 2.4 percent of man-hours lost. For 1938 figures respectively were 5.4 percent, 5.1 percent, 9.5 percent. Montmlx LaB. Rev., MFay, 1938, p. 1200; MFay, 1939, p. 1125. The 1939 statistics show a slightly higher percentage. Number of strikes run January, 6.2 percent; February, 6.9 percent; March, 6 percent; April, 7.8 percent; Mray, 4.8 percent; June, 6.7 percent. The number of workers involved as a rule follow the same course as numbar of strikes. In February, 1939, however, one very large strike (Plymouth factory, Dztroit) brought the percentage of workers up to 19.3 percent. This is unusual. 
it was only the beginning of such amendments. Once admit that an injunction may sometimes be warranted, and an opening for its return is allowed in any other case in which a majority of the legislature - or the impressionable courts - believe it warranted. But there are symbolic arguments on the other side. A boycott in such cases does give rise to a justified sense of grievance in those who feel that the Board certification should end the controversy. This sense of grievance can easily be exploited. Labor's opposition to injunction or to any authoritative means of settlement lends plausibility to the argument that labor leadership is indifferent to the injustice caused by jurisdictional disputes. So the amendment, or some other action, comes anyway, but in forms more drastic and objectionable.

Some courts have seized eagerly (without any prior administrative determination) on the mere statutory declaration of the employees' right to representatives of their choosing to give additional backing to prohibition of strike activity in jurisdictional disputes. ${ }^{170}$ Recently the Supreme Court of Washington forbade the Teamsters to boycott a brewery where the Brewers were in the majority, had a contract and indeed owned stock in the company. ${ }^{180}$ The Oregon anti-picketing act quite explicitly forbids picketing, boycott, etc., in jurisdictional disputes; and laws in Pennsylvania and Wisconsin forbidding picketing, except by a union representing a majority of employees, accomplish the same result. ${ }^{181}$ These judicial decisions and statutory declarations take the existence of a contract or majority membership in a union as establishing a choice of representatives. Yet the contract or union membership may be the result of employer coercion. A more recent pronouncement by Thurman Arnold explaining the indictments of the Teamsters and the Carpenters proceeds on a related line. ${ }^{182}$ The Anti-Trust Act will be used, he says, when the defendants seek "to destroy an established and legitimate system of collective bargaining." What is the legal basis of this "legitimacy?" It may, of course, have been established by the NLRB (though not in these cases since they involved intra-Federation disputes); it may have been established by an award of the AFL: the anti-trust laws will serve as sanction for these awards; it may be predicated on the existence of a contract or proof that the majority of employees favor the recognized union.

The philosophy of the Stillwell case is as applicable as ever, in the absence of an administrative determination. The argument may be made,

179. United Union Brewing Co. v. Beck, 5 LAB. REt. REP. 137 (Wash. 1939); McKay v. Retail Automobile Salesmen's Union, 4 LAB. ReL. Rep. 356 (Cal. 1939); E. H. Renzel Co. v. Warehousemen's Union, 4 Lar. Ret. Rep. 356 (Cal. 1939) ; Smith Metropolitan Market Co. v. Lyons, 4 LAB. ReE. Rep. 357 (Cal. 1939).

180. United Union Brewing Co. v. Beck, 5 LAB. ReL. Rep. 137 (Wash. 1939).

181. Ore. Laws 1939, c. 2; Pa. Laws 1939, Act 163; Wis. Laws 1939, c. 25.

182. N. Y. Times, Nov. 20, 1939, p. 1, col. 4 and p. 12, col. 1. 
of course, that the union should seek such a determination rather than picket. But the time may not be ripe and if it is, then it is more to the point that the employer, rather than resorting to the court, should seek a remedy from the body whose special business it is to handle such questions. ${ }^{183}$ The Court of Appeals for the District of Columbia in the Fur Workers Union case, ${ }^{18 *}$ recently affirmed by the Supreme Court, has made clear, first, that the Board and not the court is the proper forum for determining the collective bargaining agent; and second, that the Norris-LaGuardia Act forbids an injunction in these cases. A matter not within the jurisdiction of the National Labor Relations Board may arise in a state having no local board. One court which refused to follow the hands-off policy of Stillwell $v$. Kaplan itself held an election. ${ }^{18 \pi}$ This may be preferable to the pure assumption of those courts which accept any union and any contract as the free choice of the employees. But its use may offer a plausible objection to the establishment of an administrative tribunal, capable of acting with that intelligence and sensitivity developed by a constant application to one subject and possessing formal procedures devised for the matter at hand.

\section{Eptlogue: Predicament of the Author}

Department of Iustice: You admit that the jurisdictional dispute when accompanied by picket and boycott is wasteful and exasperating and that whatever justification it may have is cancelled when the fight continues for year after year without settling the issues involved.

Author: I do.

$D$. of $J_{\text {.: }}$ You admit that the AFL may fail to bring the parties to terms, that the NLRB is wary of entering the contest, and that the courts are forbidden by the Norris-LaGuardia Acts to grant injunctions. Yet you criticize us for using the anti-trust laws.

183. See discussion in Lund v. Woodenware Workers Union, 19 F. Supp. 607, 609-11 (D. Minn. 1937).

184. Fur Workers Union v. Fur Workers Union, 105 F. (2d) 1 (D. D. C. 1939), aff'd, apparently by a per curian decision of the Supreme Court, (1939) 7 Lnd. ReI. REP. 698. Where the Board had taken jurisdiction but had not yet decided the Circuit Court of Appeals for the Third Circuit forbade picketing. Union Premier Food Stores v. Retail Food Clerks and Managers Union, 98 F. (2d) \$21 (C. C. A. 3d, 1938), 101 F. (2d) 475 (C. C. A. 3d, 1939) cert. granted, 59 Sup. Ct. 1032 (U. S. 1939). On argument it was indicated the case might be moot. N. Y. Times, Dec. 7, 1939, p. 31, col. 5. AIr. Justices Hughes and Stone made remarks favorable to the position of the court below. If this power is to be exercised, it should be done by the Board itself, which is in a better position to evaluate the equities while the matter is pending.

185. Union Premier Food Stores v. Retail Food Clerks \& MIanagers Union, 98 F. (2d) 821, 826 (C. C. A. 3d, 1938), the Circuit Court of Appeals for the Third Cireuit raeated the order of the district court for an election on the ground that the Board alone had jurisdiction to order an election. 
A.: Yes, I do. I am afraid that the action of the Department may provide the courts with a moral justification for reasserting a jurisdiction over labor activities of which we have fought so long and so hard to deprive them. They, and not you, will distinguish between the legitimate and the illegitimate.

$D$. of J.: Now you have proposed that the "evil" be cured by authorizing the Labor Board to determine representatives for collective bargaining despite the existence in the case of an intra-federation dispute? Nevertheless you yourself admit that the AFL will probably never agree to such legislation and that, consequently, the chances of Congressional action are negligible.

A.: I am afraid that that is so, unless indeed your indictments convince them of the necessity of finding a better solution. Indeed, I half suspect that your move was tactical.

$D$. of J.: We will ignore your last remark and proceed. You say further that the certifications of the Board should be enforced by injunction. Yet you admit that Labor may throw all its weight against any change in the Norris-LaGuardia Act fearing lest it be an opening wedge for further hostile action.

A.: I believe I did say something like that.

$D$. of $J$.: So you admit the evil, offer no practical way of dealing with it, and yet criticize us for attempting a feasible solution.

A.: You may have me there. I might suggest, however, that there are some evil things which we must bear, because the remedy may be worse. We have suffered this condition for many years. Lapse of time does not satisfy our longing for a decent solution; but it may demonstrate that the condition is endurable. More than that it may show that no one has a mandate to deal with it. The implication from long nonuser is reinforced by the Norris-LaGuardia Act which the federal equity courts read as a Congressional expression of non-interference in jurisdictional disputes. Though that law applies in terms only to injunctions, its policy may have been directed to the anti-trust laws as well. Perhaps, then, you should await a further revelation from the Vox Populi on the Hill. In the meantime, as you have yourself told us, there is plenty of work to be done in eliminating discrimination against modern building methods and materials and allied abuses whether by Capital or Labor. In such matters it will be unnecessary to teeter along the dizzy tightrope of legitimacy, for the way is broad and clear. 